\title{
PENGEMBANGAN PROGRAM PEMBINAAN PENGAWAS PAI KEMENTERIAN AGAMA SUMATERA SELATAN
}

\author{
${ }^{1}$ Muslim Gani Yasir, ${ }^{2}$ Indah Puspa Haji \\ ${ }^{1,2}$ STIT Mambaul Hikam, Pali, Sumatera Selatan \\ e-mail: indahpuspahaji38@gmail.com
}

\begin{abstract}
Abstrak
Penelitian ini bertujuan untuk melihat bagaimana pengembangan program pembinaan pengawas PAI di lingkungan Kementerian Agama Provinsi Sumatera Selatan. Permasalahan dalam penelitian ini untuk mengetahui validitas program pembinaan pengawas, menguji kepraktisan program yang dirumuskan, dan menguji efektifitas program pengembangan yang dirumuskan. Jenis penelitian ini adalah penelitian R \& D dengan mengadaptasi model Meredith D. Gall Jolly and Bollito dalam Brian Tomlinson, dan Teori Martin Tessmer. Teknik pengumpulan data menggunakan dokumen, observasi, angket, dan test. Hasil penelitian dan pengembangan ini diharapkan dapat membantu pengawas dalam melaksanakan tugas untuk membimbing guru di wilayah kerja masing-masing. Keterbatasan penelitian ini, yaitu pada pelaksanaan uji coba pemakaian serta pada diseminasi dan implementasi. Maka dari itu, para peneliti yang akan melakukan penelitian tentang program diklat pengawas dapat menindaklanjuti hasil penelitian ini dengan mengatasi seluruh keterbatasan penelitian dan pengembangan yang sudah dilakukan atau memanfaatkan hasil penelitian dan pengembangan ini untuk penelitian sejenis.
\end{abstract}

Kata Kunci : Pengembangan Program, Pembinaan Pengawas, Pendidikan Agama Islam

\begin{abstract}
This research aims to see how the development of the PAI supervisory development program in the Ministry of Religion of South Sumatra Province. The problem in this research is to determine the validity of the supervisory development program, to test the practicality of the formulated program, and to test the effectiveness of the formulated development program. This research type is $\mathrm{R} \& \mathrm{D}$ research by adapting the model of Meredith D. Gall Jolly and Bollito in Brian Tomlinson, and Martin Tessmer's Theory. Data collection techniques using documents, observations, questionnaires, and tests. The results of this research and development are expected to assist supervisors in carrying out their duties to guide teachers in their respective work areas. The limitations of this research, namely the implementation of the trial use as well as the dissemination and implementation. Therefore, researchers who will conduct research on supervisory training programs could follow up on the results of this research by overcoming all the limitations of research and development that have been carried out or utilizing the results of this research and development for similar research.
\end{abstract}

Keywords: Program Development, Supervisor Development, Islamic Education 


\section{A. Pendahuluan}

Salah satu permasalahan yang dihadapi oleh pengawas pendidikan agama Islam pada sekolah di Sumatera Selatan adalah belum diberikan kewenangan penuh dalam melaksanakan tugas dan fungsi kepengawasan sesuai dengan yang tertuang dalam Keputusan Menteri Agama nomor 2 tahun 2012 tentang Pengawas madrasah dan pengawas Pendidikan Agama Islam di sekolah. Pengawas Pendidikan Agama Islam pada sekolah mempunyai fungsi melakukan penyusunan program pengawasan Pendidikan Agama Islam, pembinaan, pembimbingan dan pengembangan profesi guru Pendidikan Agama Islam, pemantauan penerapan standar nasional Pendidikan Agama Islam, penilaian hasil pelaksanaan program pengawasan dan pelaporan pelaksanaan tugas kepengawasan.

Pengawas diperlukan dalam rangka membantu dalam peningkatan efektivitas pembelajaran. Selain itu, yang tidak kalah pentingnya adalah peran kepala sekolah, namun di sisi lain fungsi ini dapat juga berperan sebagai penentu efektivitas pembelajaran adalah terletak dari pembinaan pengawas. Kedua fungsi ini merupakan sama-sama penting, karena seorang kepala sekolah dalam menjalankan tugas manajerialnya harus mempertimbangkan tingkat kompetensi guru yang dipimpinnya, mengingat guru merupakan ujung tombak perubahan menuju perbaikan kinerja sekolah. Apapun yang disampaikan oleh kepala sekolah senantiasa tidak mendapatkan respon yang baik. Lebih-lebih perilaku guru yang sengaja menghidar berhadapan dengan kepala sekolah lantaran selalu tidak sepaham dengan berbagai kebijakan yang diambil. Fenomena perilaku guru dan kepala sekolah seperti tersebut di atas akan mengakibatkan kinerja sekolah yang tidak baik. ${ }^{1}$

Secara terminologis, supervisi pembelajaran sering diartikan sebagai serangkaian usaha bantuan kepada guru. Terutama bantuan yang berwujud layanan profesional yang dilakukan oleh kepala sekolah, dan pengawas serta supervisor lainnya untuk meningkatkan proses dan hasil belajar. ${ }^{2}$ Oleh karena itu, pemerintah melalui

\footnotetext{
1 Hendarman, Revolusi Kinerja Kepala Sekolah (Jakarta: Permata Puri Media, 2015), 8

2 Ali Imron, Supervisi Pembelajaran Tingkat Satuan Pendidikan (Jakarta: Bumi Aksara, 2011), 8
} 
kementerian, pernah membuat pedoman supervisi pembelajaran sebagai salah satu perangkat dalam pedoman pelaksanaan kurikulum. ${ }^{3}$ Dalam rumusan yang lebih rinci, dikemukakan bahwa tujuan supervisi pembelajaran adalah memperbaiki tujuan khusus mengajar guru dan belajar siswa, memperbaiki materi (bahan) dan kegiatan belajar mengajar, memperbaiki metode, yaitu cara mengorganisasi kegiatan belajar mengajar, memperbaiki penilaian atas media, memperbaiki penilaian proses belajar mengajar dan hasilnya, memperbaiki pembimbingan siswa atas kesulitan belajarnya, dan memperbaiki sikap guru atas tugasnya. ${ }^{4}$

Supervisi sesungguhnya dapat dilakukan oleh kepala sekolah yang berperan sebagai supervisor tetapi dalam sistem organisasi modern diperlukan supervisor khusus yang lebih independen, dan dapat meningkatkan obyektivitas dalam pembinaan dan pelaksanaan tugas. ${ }^{5}$ Untuk meningkatkan efektivitas, tugas kepengawasan ini perlu diformulasikan sedemikian rupa bagaimana program pembinaan yang tepat dalam melaksanakan fungsi ini. Jika tercipta program pembinaan yang tepat dalam melaksanakan pembelajaran maka diharapkan efektivitas pembelajaran akan tercapai dengan baik mengingat bahwa "Efektivitas menggambarkan proses atau langkahlangkah kegiatan yang harus ditempuh untuk mencapai tujuan". ${ }^{6}$

Perencanaan kurikulum yang lengkap bisa dimulai dari rumusan tujuannya bahan ajarnya, sampai pada evaluasinya. Tanpa perencanaan usaha penataan kelas tidak sebaik yang diharapkan. ${ }^{7}$ Perencanaan tidak berakhir hanya pada rancangan awal wacana tapi harus mencakup proses implementasinya. ${ }^{8}$ Karena itu, segala sesuatu yang dimasukkan dalam putusan kebijakan tersebut perlu dipertimbangkan dengan secermat mungkin

\footnotetext{
3 Ali Imron, Supervisi Pembelajaran Tingkat...., 6

4 Ali Imron, Supervisi Pembelajaran Tingkeat...., 11

5 Daryanto dan Tutik Rachmawati, Supervisi Pembelajaran, Inspeksi Meliputi Controlling, Correcting, Judging, Directing, Demonstration (Jakarta: Grava Media, 2015), 3

6 Acim Surachim, Efektivitas Pembelajaran Pola Pendidikan Sistem Ganda (Bandung: Alfabeta, 2016),138

7 Nurbaiti, Pengelolaan Kelas (Classroom Management) (Surakarta: CV. Mitra Banua Kreasindo, 2016), 24

8 Ahmad Rifa'i, Pelaksanaan Manajemen Kurikulum Sistem Blok di Program Studi Agribisnis Fakultas Industri Halal UNU Yogyakarta. An Nur: Jurnal Studi Islam, Vol. 12 No.2, (2020), 209-230.
} 
fisibilitas (feasibility) atau kelayakannya. Perencanaan yang baik adalah yang dapat dilaksanakan. ${ }^{9}$ Adapun fungsi dan tujuan perencanaan adalah sebagai pedoman pelaksanaan dan pengendalian, menghindari pemborosan sumber daya, alat bagi pengembangan quality assurance, dan upaya untuk memenuhi accountability kelembagaan. ${ }^{10}$

Bahwa organisasi kelas tidak hanya berfungsi sebagai dasar terciptanya interaksi guru dan siswa, tetapi juga menambah terciptanya efektivitas, yaitu interaksi yang bersifat kelompok. Hasil penelitian telah disimpulkan beberapa variabel masalah yang perlu diperhatikan untuk membuat iklim kelas yang efektif dan sehat, yaitu: Jika situasi kelas memungkinkan anak-anak belajar secara maksimal, fungsi kelompok harus diminimalkan, manajemen kelas harus memberi fasilitas untuk mengembangkan kesatuan dan kerjasama, anggota-anggota kelompok harus diberi kesempatan berpartisipasi dalam pengambilan keputusan yang memberi efek kepada hubungan dan kondisi belajar, anggota-anggota kelompok harus dibimbing dalam menyelesaikan kebimbangan, ketegangan dan perasaan tertekan dan perlu diciptakan persahabatan kepercayaan yang kuat antar siswa. ${ }^{11}$ Guru bertanggung jawab atas perkembangan potensi-potensi anak didik secara terpadu, baik kecerdasan otaknya, emosionalnya, maupun spiritualnya. Selain itu, modal pembelajaran hendaknya mengacu pada rekomendasi UNISCO yaitu learning to know, learning to do, learning to be dan learning to live together. ${ }^{12}$

Selanjutnya, pelaksanaan evaluasi sangat berperan mengingat evaluasi adalah suatu proses berkelanjutan tentang pengumpulan dan penafsiran informasi untuk menilai (assess) keputusan-keputusan yang dibuat dalam merancang suatu sistem pembelajaran. ${ }^{13}$ Prinsip dasar evaluasi hasil belajar dapat dikatakan terlaksana dengan

\footnotetext{
9 Udin Syaefuddin Su'ud dan Abin Syamsuddin Makmun, Perencanaan Pendidikan Suatu Pendekatan Komprehenship (Bandung: Remaja Rosdakarya, 2007), 17

${ }^{10}$ Udin Syaefuddin Su'ud dan Abin Syamsuddin Makmun, Perencanaan Pendidikan Suatu....,5

11 Nurbaiti, Pengelolaan Kelas (Classroom Management)..., 75

${ }^{12}$ Hasbullah, Otonomi Pendidikan, Kebijakan otonomi Daerah dan Implikasinya terhadap Penyelenggaraan Pendidikan, (Jakarta : Rajawali Pers, 2010), 44

13 Oemar Hamalik, Perencanaan Pengajaran Berdasarkan Pendekatan Sistem (Jakarta: Bumi Aksara, 2014), 210
} 
baik jika dalam pelaksanaannya senantiasa berpegang pada 3 prinsip dasar yaitu prinsip keseluruhan atau prinsip menyeluruh juga dikenal dengan istilah prinsip komprehenship, prinsip kesinambungan yaitu prinsip bulat utuh menyeluruh juga dikenal dengan kontinuitas, dan prinsip obyektivitas yaitu prinsip yang dapat terlepas dari faktor-faktor subyektifitas. ${ }^{14}$

Pentingnya supervisi sebagai layanan dan bantuan kepada guru untuk mencapai guru yang profesional karena secara terminologi bahwa supervisi pembelajaran sering diartikan sebagai serangkaian bantuan kepada guru. Terutama bantuan yang berwujud layanan profesional yang dilakukan oleh kepala sekolah, dan pengawas serta supervisor lainnya untuk meningkatkan proses dan hasil belajar, ${ }^{15}$ sedangkan pengembangan model supervisi terdiri dari model konvensional, model ilmiah, model klinis, dan model artistik. ${ }^{16}$ Lebih jauh dikemukakan bahwa supervisi merupakan bagian yang tidak terpisahkan dari seluruh proses administrasi pendidikan yang ditujukan terutama untuk mengembangkan efektivitas kinerja personalia sekolah yang berhubungan dengan tugastugas utama pendidikan. Dalam definisi ini, supervisi dipandang sebagai subsistem dari sistem administrasi sekolah. Sebagai subsistem, supervisi tidak terlepas dari sistem administrasi yang juga menyangkut non-guru, namun titik berat dari supervisi tersebut adalah perbaikan dan pengembangan kinerja profesional yang menangani para peserta didik. Melalui perbaikan dan pengembangan kinerja mereka, diharapkan usaha pembimbingan, pengajaran dan pelatihan peserta didik juga dapat berkembang, serta secara langsung dapat meningkatkan efektivitas proses belajar-mengajar. ${ }^{17}$ Pada sisi lain dikemukakan bahwa "Supervision a process designed to help teacher and supervisor learn more about their practice; to better able to use their knowledge ang skills to better serve parents and schools; and to make the school a more effective learning community". ${ }^{18}$

14 Anas Sudijono, Pengantar Evaluasi Pendidikan (Jakarta: PT. Raja Grafindo Persada, 2007), 31-32

15 Ali Imron, Supervisi Pembelajaran Tingkat Satuan Pendidikan (Jakarta: Bumi Aksara, 2011), 8

16 Piet A. Sahertian, Konsep Dasar dan Teknik Supervisi Pendidikan dalam Rangka Pengembangan Sumber Daya Manusia (Jakarta: Rineka Cipta, 2000), 34

17 E. Mulyasa, Manajemen dan Kepemimpinan Kepala Sekolah (Jakarta: Bumi Aksara, 2012), 240

18 E. Mulyasa, Manajemen dan Kepemimpinan...., 252 
Pentingnya penelitian ini dilakukan dalam rangka merumuskan program yang tepat bagi supervisor dalam melaksanakan supervisi pembelajaran terhadap guru dalam melaksanakan kegiatan pembelajaran di kelas sehingga dapat menghasilkan pembelajaran yang efektif. Fokus penelitian ini adalah peningkatan kompetensi pengawas Pendidikan Agama Islam di sekolah umum sesuai dengan Peraturan Menteri Agama Republik Indonesia nomor 2 Tahun 2012 tentang Pengawas Madrasah dan Pengawas Pendidikan Agama Islam pada sekolah, sedangkan judul penelitian ini adalah pengembangan program pembinaan pengawas pendidikan agama Islam di lingkungan Kementerian Agama Provinsi Sumatera Selatan.

\section{B. Metodologi Penelitian}

1. Pengertian Model Pengembangan

Model pengembangan merupakan dasar untuk mengembangkan produk yang akan dihasilkan. Model pengembangan dapat berupa model prosedural, model konseptual, dan model teoritik. Model prosedural adalah model yang bersifat deskriptif, menunjukkan langkah-langkah yang harus diikuti untuk menghasilkan produk. ${ }^{19}$ Penelitian jenis ini berbeda dengan penelitian pendidikan lainnya karena tujuannya adalah mengembangkan produk berdasarkan uji coba untuk kemudian direvisi sampai menghasilkan produk yang layak pakai. Borg and Gall menyatakan bahwa penelitian pengembagan adalah suatu proses yang digunakan untuk mengembangkan dan memvalidasi produk-produk yang digunakan dalam pendidikan dan pembelajaran. ${ }^{20}$

Menurut Sugiyono, model penelitian Research and Development yang selanjutnya disingkat $\mathrm{R}$ \& $\mathrm{D}$ adalah model penelitian yang digunakan untuk menghasilkan produk tertentu, dan menguji keefektifan produk tersebut, baik bidang

19 Sugiyono, Metode Penelitian Kuantitatif, Kualitatif, dan Kombinasi (Mixed Methods) (Bandung: Alfabeta, 2012), 2

20 Sugiyono, Metode Penelitian Kuantitatif....., 4 
administrasi, pendidikan, sosial, dan lainnya. ${ }^{21}$ Model Desain Research and Development (R \& D) yang akan digunakan adalah Model Educational Research And Development. Untuk itu, penelitian ini secara spesifik digolongkan ke dalam jenis penelitian pengembangan program pengajaran (developing of intruction program), yaitu suatu penelitian yang digunakan untuk mengembangkan dan memvalidasi produk pendidikan. ${ }^{22}$

\section{Tujuan Penelitian Pengembangan}

Pada tujuan penelitian pengembangan, biasanya berisi dua informasi, yaitu masalah yang akan dipecahkan dan spesifikasi pembelajaran, model, soal, atau perangkat yang akan dihasilkan untuk memecahkan masalah tersebut. ${ }^{23}$ Penelitian ini lebih melihat pada perkembangan karakteristik setiap subyek yang menjadi fokus penelitian. Kajian cross sequential, yaitu kombinasi kedua metode di atas yang berusaha perpendek lamanya waktu dan meminimalisasi asumsi-asumsi perkembangan.

3. Karakteristik dan Motif Penelitian Pengembangan

Karakteristik penelitian pengembangan antara lain: (a) Masalah yang ingin dipecahkan adalah masalah nyata yang berkaitan dengan upaya inovatif atau penerapan teknologi dalam pembelajaran sebagai pertanggung jawaban profesional dan komitmennya terhadap pemerolehan kualitas pembelajaran, (b) Pengembangan program, pendekatan dan metode pendidikan dan pelatihan serta media yang digunakan untuk menunjang keefektifan pencapaian kompetensi, (c) Proses pengembangan produk, validasi yang dilakukan melalui uji ahli, dan uji coba lapangan secara terbatas perlu dilakukan sehingga produk yang dihasilkan bermanfaat untuk peningkatan kualitas pembelajaran. Proses pengembangan, validasi, dan uji coba lapangan tersebut seyogyanya dideskripsikan secara jelas, sehingga dapat dipertanggung jawabkan secara akademik, (d) Proses pengembangan, model,

21 Sugiyono, Metode Penelitian Kuantitatif...., 298

22 Walter R. Borg and Meredith D. Gall, Joyce P. Gall, Educational Research (Introduction) (USA: Pearson Education, 2007), 772

23 Walter R. Borg and Meredith D. Gall, Joyce P. Gall, Educational Research (Introduction)..., 417 
pendekatan, modul, metode, dan media pembelajaran perlu didokumentasikan secara rapi dan dilaporkan secara sistematis sesuai dengan kaidah penelitian yang mencerminkan originalitas.

Adapun motif penelitian dan pengembangan antara lain : (a) Motif dasarnya bahwa penelitian kebanyakan dilakukan bersifat tradisional, seperti eksperimen, survey, analisis korelasi yang fokusnya pada analisis deskriptif yang tidak memberikan hasil yang berguna untuk desain dan pengembangan dalam pendidikan, (b) Keadaan yang sangat kompleks dari banyaknya perubahan kebijakan di dalam dunia pendidikan, sehingga diperlukan pendekatan penelitian yang lebih evolusioner (interaktif dan siklis), (c) Penelitian bidang pendidikan secara umum kebanyakan mengarah pada reputasi yang ragu-ragu dikarenakan relevasi ketiadaan bukti.

4. Kelebihan dan Kelemahan Penelitian Pengembangan

Berikut ini kelebihan penelitian pengembangan atau Research and Development yaitu sebagai berikut: (a) Penelitian dan pengembangan atau Research and Development mampu menghasilkan suatu produk atau program yang memiliki nilai validasi tinggi karena produk tersebut dihasilkan melalui serangkaian uji coba di lapangan dan validasi oleh ahli, (b) Penelitian dan pengembangan atau Research and Development akan selalu mendorong proses inovasi produk atau model yang tiada henti atau memiliki nilai suistanibility yang cukup baik sehingga diharapkan akan ditemukan produk-produk atau program-program yang selalu aktual sesuai dengan tuntutan kekinian, (c) Penelitian dan pengembangan atau Research and Development merupakan penghubung antara penelitian yang bersipat teoritis dengan penelitian yang bersipat praktis, (d) Metode Penelitian dan pengembangan atau Research and Development merupakan metode yang cukup komprehenshif, mulai dari metode deskriptif, evaluatif, dan eksperimen.

Kelemahan Penelitian dan pengembangan atau Research and Development yaitu sebagai berikut: (a) Pada prinsipnya Penelitian dan pengembangan atau Research and Development memerlukan waktu yang relatif panjang karena prosedur yang harus ditempuhpun relatif kompleks, (b) Penelitian dan pengembangan atau Research and 
Development dapat dikatakan sebagai penelitian "bere and now", Penelitian R\&D tidak mampu digeneralisasikan secara utuh, karena pada dasarnya R\&D pemodelannya pada sampel bukan pada populasi.

5. Model Tahapan Penelitian Pengembangan

Tahapan dalam penelitian pengembangan yang biasa dilakukan dalam dunia pendidikan yaitu : (a) Pemeriksaan pendahuluan (preliminary investigation). Pemeriksaan pendahuluan yang sistematis dan intensif dari permasalahan mencakup; (1) Tinjauan ulang literatur, konsultasi tenaga ahli, (2) Analisa tentang ketersediaan contoh untuk tujuan yang terkait, dan (3) Studi kasus dari praktek yang umum untuk merincikan kebutuhan, (b) Penyesuaian teoritis (theoritical embedding). Usaha yang lebih sistematis dibuat untuk menerapkan dasar pengetahuan dalam mengutarakan dasar pemikiran yang teoritis untuk pilihan rancangan, (c) Uji empiris (empirical testing). Bukti empiris yang jelas menunjukkan tentang kepraktisan dan efektivitas dari intervensi, (d) Proses dan hasil dokumentasi, analisa dan refleksi (dokumentation, analysis, and reflection on process and outcome)..

6. Prosedur Pengembangan

Menurut Sugiyono langkah-langkah penelitian R\&D secara ringkas dapat dijelaskan sebagai berikut: (a) Potensi dan masalah, (b) Mengumpulkan informasi, (c) Desain produk, (d) Validasi desain, (e) Perbaikan desain, (f) Uji coba produk, (g) Revisi produk, (h) Uji coba pemakaian, (i) Revisi produk, dan (j) Pembuatan produk massal.

\section{Hasil dan Pembahasan}

\section{Hasil Identifikasi Masalah dan Analisis Kebutuhan Program Pembinaan Pendidikandan Pelatihan Pengawas PAI}

Pengumpulan informasi awal dari lapangan berupa data analisis kebutuhan (need analysis) dilakukan sesuai theori Jolly and Bolitho dalam Brian Tomlinson Walter Dick, sejalan dengan tujuan yang disampaikan Cunningsworth. Tahapan 
Studi pendahuluan dilakukan untuk memperoleh tanggapan dari calon pengguna dan kajian terhadap program pembinaan pengawas PAI Kantor Wilayah Provinsi Sumatera Selatan, analisis program pembinaan pengawas, kebutuhan program pembinaan pengawas. Pengumpulan informasi dilakukan menggunakan studi lapangan/survei, wawancara, studi literatur/dokumentasi, angket. Survei dan dokumentasi dilakukan terhadap program pembinaan yang dilakukan selama ini. Angket diberikan kepada pengawas PAI dalam upaya mencari masukan tentang program pembinaan pengawas PAI yang selama ini dilakukan dan program pembinaan pengawas PAI yang akan dikembangkan dan diskusi akhir dengan para pengawas PAI.

a. Hasil Survei, dokumentasi, dan wawancara

Studi pendahuluan ini adalah yang menjadi acuan dan dasar hukumnya adalah Keputusan Menteri Agama Nomor 2 Tahun 2012 tentang Pengawas Madrasah dan Pengawas Pendidikan Agama Islam di sekolah. Berbagai problem yang ada pada pengawas PAI saat ini adalah perlu pengembangan program pembinaan berupa pendidikan dan pelatihan bagi pengawas dalam rangka menambah wawasan dalam membina guru agama, dalam hal ini kebutuhan yang mendasar adalah berupa diklat kompetensi pedagogik pengawas yang sangat diperlukan dan perlu peningkatan kompetensi ini. Selama ini, pengawas PAI dapat menjalankan tugasnya hanya sebatas monitoring dan evaluasi dengan mengisi dan membuat catatan-catatan pada lembar monitoring berupa daftar isian (blangko) saja. Tetapi untuk memberikan pembinaan dan bimbingan berupa arahan berupa teknik-teknik mengajar dan cara mengatasi problem permasalahan dalam proses belajar mengajar di kelas selama ini belum dilaksanakan dikarenakan masih diperlukannya model yang tepat agar fungsi ini dapat terlaksana sesuai dengan kebutuhan baik terhadap pengawas maupun terhadap guru dan murid itu sendiri.

Analisis kebutuhan program pembinaan pengawas adalah proses awal dalam menyusun program pembinaan pendidikan dan pelatihan bagi pengawas PAI. Analisis ini bertujuan agar program pendidikan dan pelatihan yang dirumuskan sesuai dengan tuntutan kompetensi yang harus dikuasai oleh 
pengawas. Analisis ini meliputi tiga tahapan, yaitu analisis terhadap kurikulum dan tujuan diklat, analisis materi diklat, dan analisis evaluasi diklat. Ketiga proses tersebut menjadi bagian integral dari suatu proses pembuatan program pembinaan pendidikan dan pelatihan pengawas PAI.

b. Hasil Angket Kebutuhan Pengawas terhadap Program Pembinaan Pengawas PAI

Hasil angket yang dijadikan acuan adalah rendahnya kemampuan pengawas dalam memberikan pembinaan kepada guru yang ia bina terhadap kemampuan guru dalam memenage kelas yakni kurangnya kreativitas dalam melaksanakan model-model pembelajaran di kelas sehingga membuat pembelajaran yang selama ini menjadi kurang menarik bagi siswa. Dengan adanya analisis ini diharapkan dapat memberikan suasana belajar yang menggairahkan bagi peserta didik dalam mengikuti pembelajaran PAI di kelas.

\section{Hasil Perencanaan/Planning Desain Awal (Prototype) Program Pembinaan Pendidikan dan Pelatihan Pengawas PAI}

a. Latar Belakang Program

Hasil penelitian Puslitbang Pendidikan Agama dan Kegamaan bahwa Pengawas PAI memiliki kemampuan substansi PAI dengan kategori baik, sedangkan untuk proses supervisi pembelajaran, penelitian dan pengembangan dan pengusaan penilaian masih rendah. Selaras dengan hasil temuan penelitian tersebut, dan juga suatu kenyataan bahwa rasio guru PAI dan pengawas PAI belum memenuhi ketentuan sebagaimana ditetapkan dalam peraturan perundangundangan yang berlaku. Untuk mengoptimalkan tugas pengawas PAI dengan kondisi yang tidak sebanding tersebut, maka diperlukan langkah-langkah konkrit agar pengawas PAI yang ada memiliki kompetensi yang baik, sehingga dalam melaksanakan tugasnya pengawas PAI ini dapat bekerja secara proporsional dan profesional. Langkah-langkah tersebut di antaranya adalah program diklat singkat bagi pengawas PAI. 
b. Bentuk Program

Adapun bentuk program pembinaan Pengawas PAI ini adalah berupa Pendidikan dan Pelatihan Singkat Model-model Pembelajaran Inovatif selama 32 jam pelajaran atau setara dengan 4 (empat) kali pertemuan.

c. Tujuan Program

1) Meningkatkan kompetensi pedagogik pengawas PAI dalam membimbing guru pada proses belajar dengan menggunakan model-model pembelajaran inovatif di kelas;

2) Memberikan bekal pengetahuan kepada pengawas tentang model-model pembelajaran;

3) Membekali pengalaman pengawas PAI dengan simulasi-simulasi model pembelajaran secara inovatif;

4) Membantu pengawas dalam mengatasi problem guru untuk menerapkan model-model pembelajaran yang tepat sesuai dengan materi yang akan diajarkan pada Proses Belajar Mengajar di kelas;

5) Memberikan solusi dalam penerapan materi pembelajaran sehingga dapat memberikan dampak terhadap peningkatan prestasi belajar siswa;

6) Memberikan berbagai alternatif variasi metode guru dalam mengajar dan penguasaan kelas;

7) Memberikan pengetahuan kepada pengawas tentang berbagai metode dan model pembelajaran untuk diterapkan kepada guru yang dibinanya;

8) Membekali pengetahuan pedagogik pengawas PAI dalam menyusun rencana program pengawasan;

9) Meningkatkan kinerja pengawas PAI dalam melaksanakan tugas sehingga dapat memberikan kepercayaan diri dihadapan guru-guru binaannya; 
10) Menambah pengetahuan dan keterampilan pengawas PAI dalam melaksanakan pembimbingan dan pelatihan profesionalitas guru;

11) Mengarahkan pengawas PAI dalam melaksanakan tugas pengawasan akademik yang meliputi pembinaan dan pemantauan standar nasional.

d. Sasaran

Sasaran program ini adalah seluruh pangawas PAI Kementerian Agama Provinsi Sumatera Selatan yang berjumlah 97 orang; yang tersebar pada beberapa Kabupaten/Kota.

e. Target

Target-target yang harus dikuasai adalah (1) membekali seluruh pengawas PAI Kementerian Agama Provinsi Sumatera Selatan sebanyak 97 orang di 17 Kabupaten/Kota dan terdiri dari Pengawas PAI TK/SD, SMP, SMA/SMK dalam melaksanakan fungsi pengawasan untuk memberikan bimbingan kepada guru dalam menguasai kelas, (2) melaksanakan pengajaran yang menyenangkan, (3) mencari solusi terhadap permasalahan guru dalam mengatasi penyampaian materi pembelajaran yang memerlukan strategi khusus dan membantu guru dalam memberikan penanaman akhlak kepada siswa serta menjadikan guru sebagai tauladan bagi siswanya.

f. Langkah-langkah Pembinaan Pengawas PAI

Adapun langkah-langkah pembinaan pengawas PAI dalam penelitian ini terdiri dari:

1) Pertemuan awal;

2) Pretest;

3) Penyampaian materi diklat;

4) Simulasi/demonstrasi/peer teaching atau praktek mengajar bagi pengawas sebagai peserta diklat setelah pengawas mendapatkan materi dan contohcontoh dari nara sumber; 
5) Postest.

g. Pelaksana Kegiatan

1) Pelaksana kegiatan ini adalah Ketua Kelompok Kerja Pengawas PAI Kantor Wilayah Kementerian Agama Provinsi Sumatera Selatan; dan

2) Organisasi Pengawas di bawah naungan Kementerian Agama Provinsi Sumatera Selatan.

h. Biaya

Biaya kegiatan penelitian ini dapat dilihat secara lebih komprehensif sebagaimana berikut:

\begin{tabular}{|c|c|c|}
\hline No & Kegiatan & Jumlah \\
\hline 1 & ATK dan Suplies Komputer & Rp. 2.000.000,- \\
\hline 2 & Dokumentasi (50 Eks Rp.2000) & Rp. $\quad 200.000,-$ \\
\hline 3 & Spanduk kegiatan (2 PcsxRp.100.000) & Rp. $\quad 200.000,-$ \\
\hline 4 & Penggandaan dan penjilidan laporan & Rp. $\quad 100.000,-$ \\
\hline 5 & Honor panitia 4 orang & Rp. 1.400.000,- \\
\hline 6 & Honor Narasumber (32 JPLxRp.400.000) & Rp.12.800.000,- \\
\hline 7 & Honor Moderator & Rp. 3.200.000,- \\
\hline 8 & Uang harian peserta, Panitia (40 orangxRp.85.000) & Rp. 3.400.000,- \\
\hline 9 & $\begin{array}{l}\text { Transport panitia, moderator dan narasumber (6 } \\
\text { orangxRp.100.000) }\end{array}$ & Rp. $\quad 600.000,-$ \\
\hline 10 & Transport peserta (36 orang x Rp.100.000) & Rp. 3.600.000,- \\
\hline 11 & $\begin{array}{l}\text { Konsumsi snek dan makan siang (40 orang } \times 4 \\
\text { HarixRp.50.000) }\end{array}$ & Rp. 8.000.000,- \\
\hline & Jumlah & Rp.34.600.000,- \\
\hline
\end{tabular}

i. Metode Pembinaan 
Metode pembelajaran dalam diklat ini terdiri dari metode tanya jawab, presentasi, diskusi dan demonstrasi.

j. Media Pembinaan

Media yang digunakan dalam pelaksanaan diklat ini terdiri dari demonstrasi langsung, memutar video, dan simulasi project base serta menerapkan model-model inovatif model baru.

k. Evaluasi

Evaluasi dalam pelaksanaan diklat ini terdiri dari pretest dan posttest, peer teaching, monitoring dan evaluasi secara berkala.

1. Tindak Lanjut Hasil Pembinaan

Setiap pengawas yang telah mengikuti kegiatan ini diwajibkan untuk menyampaikan hasil diklat yang telah diperoleh kepada guru-guru PAI yang dibinanya masing-masing dengan cara pelaksanaan diklat yang sama secara bertahap dengan mengalokasikan waktu pada jadwal kunjungan pengawas kepada guru binaannya. Demikian pula halnya setelah melaksanakan kegiatan pembinaan kepada guru PAI yang dibina agar dimonitoring dan dievaluasi sampai sejauh mana program pembinaan yang diberikan dapat direalisasikan pada proses belajar mengajar di sekolah masing-masing.

m. Materi Diklat

Materi diklat ini terdiri dari berbagai model-model pembelajaran yang sangat diperlukan dalam proses pembelajaran seperti: Peer Teaching, Card sort, The power of two, Index card match, Reading guide, Psycal Self Asessment, True or false, Small group discussion, PCP (point counterpoint), Everyone is a teacher here, Jigsaw learning, Gallery session, Active knowledge sharing, Bingo, Information search, Question student have, Dinamic true or false, dan Poster session. 


\section{Hasil Pengembangan Program Pembinaan Pendidikan dan Pelatihan Pengawas PAI}

Hasil pengembangan dari program ini disesuaikan dengan kebutuhan di lapangan, dengan memperhatikan berbagai masukan dan saran baik dari ahli validasi aupun masukan dari pengawas itu sendiri, dengan menguraikan secara rinci tentang materi pendidikan dan pelatihan model-model pembelajaran.

\section{Hasil Validasi Produk Progam Pembinaan Pendidikan dan Pelatihan Pengawas PAI}

a. Hasil Validasi Ahli Materi Program

Dari tabel di atas dapat diketahui bahwa hasil validasi program terhadap program pembinaan pengawas adalah sebesar $97,65 \%$. Komentar dan saran ahli program/materi, ada beberapa poin yang perlu diperbaiki untuk penyempurnaan program yaitu disarankan sebagai berikut :

1) Harus ada pengertian dari masing-masing model pembelajaran;

2) Harus ada pengertian dari masing-masing model pembelajaran;

3) Kelebihan dan kekurangan model pembelajaran;

4) Langkah-langkah penggunaannya;

5) Kecocokan model dengan materi pengawasan.

b. Hasil Validasi Ahli Kurikulum

Hasil validasi yang diperoleh dari ahli kurikulum terhadap program pembinaan pengawas adalah sebesar 97,06 \%. Ada beberapa poin yang perlu diperbaiki untuk penyempurnaan program, khususnya pada tujuan program yaitu disarankan sebagai berikut:

1) Meningkatkan wawasan perencanaan pembelajaran; 
2) Meningkatkan implementasi pembelajaran;

3) Meningkatkan evaluasi proses pembelajaran;

4) Meningkatkan evaluasi hasil pembelajaran.

5) Sampelnya tidak perlu seluruh pengawas;

6) Ini bukan penelitian pengawas, tapi pengembang program (prototipe program);

7) Tidak perlu menyebutkan semua model pembelajaran disebut juga tidak akan mungkin melatihkan semuanya;

8) Cukup disebutkan materinya berhubungan dengan strategi pembelajaran, pendekatan, model, metode, teknik dan taktik.

c. Hasil Validasi Ahli Bahasa

Hasil validasi bahasa terhadap program pembinaan pengawas adalah sebesar 94,12\%. Komentar dan saran ahli bahasa, ada beberapa poin yang perlu diperbaiki untuk penyempurnaan program yaitu disarankan sebagai berikut :

1) Perbaiki sistematika penulisan;

2) Pertegas penulisan kalimat agar maksudnya jelas;

3) Beri cetak miring pada penggunaan kata-kata asing;

4) Patuhi aturan tentang penulisan catatan kaki dan kutipan;

5) Sajikan power point dengan tampilan yang menarik.

\section{Hasil Perbaikan Desain Awal Prototype Program Pembinaan Pendidikan dan Pelatihan Pengawas PAI}

Dari beberapa poin yang disarankan berdasarkan tiga ahli sebagai validator yakni ahli program, ahli kurikulum dan ahli bahasa, maka program mengalami beberapa perbaikan demi untuk kesempurnaan program yang dibuat. 


\section{Hasil Evaluasi Satu-satu/One-to-one Evaluation terhadap Prototype Program Pembinaan Pendidikan dan Pelatihan Pengawas PAI}

Program pengembangan pembinaan pengawas PAI Kementerian Agama Provinsi Sumatera Selatan untuk meningkatkan kompetensi pengawas PAI mempunyai nilai respon yang sangat baik. Hal ini dapat dilihat dari besarnya prosentase yang diberikan oleh responden yaitu sebesar 98,6 \%.

\section{Hasil Evaluasi Kelompok Kecil/Small Group terhadap Prototype Program Pembinaan Pendidikan dan Pelatihan Pengawas PAI}

Dari data yang dihimpun sebagai masukan dan komentar dari uji coba lapangan dalam pernyataan terbuka berkenaan dengan produk program pembinaan pengawas PAI yang telah diujicobakan yaitu: Responden merasa lebih mudah dalam memahami materi pada program yang dikembangkan, responden merasa lebih mudah dalam melaksanakan kegiatan program yang dikembangkan, responden merasa lebih mudah dalam mengikuti petunjuk kegiatan pada modul program yang dikembangkan, responden merasa lebih mudah dalam melaksanakan tugas dengan adanya program kegiatan, responden merasa sangat senang mengikuti materi program yang dikembangkan, responden merasa lebih tertarik dengan materi yang disajikan dalam materi program yang dikembangkan, responden merasa pemahaman tugas kepengawasan dapat meningkat setelah mengikuti program pengembangan modul ini, responden merasa menambah semangat untuk meningkatkan tugas kepengawasan dengan adanya materi pada program yang dikembangkan, responden merasa materi pada program yang dikembangkan dapat memberikan keingin tahuan yang lebih tinggi, responden merasa materi pada program yang dikembangkan materinya sangat mudah untuk diterapkan, responden merasa materi yang dikembangkan sangat sesuai dengan keadaan guru yang dibina, dan responden merasa materi pada program ini dapat meningkatkan kompetensi yang berkaitan tugas kepengawasan. 


\section{Hasil Revisi Desain Akhir}

Revisi desain akhir terhadap pengembangan program pembinaan pengawas PAI Kementerian Agama Sumatera Selatan dilakukan setelah melalui beberapa tahap, mulai dari analisis dan identifikasi kebutuhan, perencanaan dan pengembangan / penyusunan desain/prototipe program pembinaan, self evaluation (revisi), penilaian tim ahli/expert review (revisi), one-to-one evaluaton (revisi), dan small group evaluation (revisi), yang menunjukkan program pembinaan pengawas PAI melalui pendidikan dan pelatihan singkat memiliki kepraktisan. Produk hasil pengembangan ini siap digunakan sebagai bahan untuk diklat bagi pengawas PAI Kementerian Agama Sumatera Selatan, dan dapat diuji cobakan keefektifannya pada diklat pengawas PAI Provinsi Sumatera Selatan.

\section{Hasil Uji Coba Pemakaian/Field Test terhadap Program Pembinaan Pendidikan dan Pelatihan Pengawas PAI}

Kesimpulan yang dapat ditarik di sini adalah, berdasarkan hasil uji coba tersebut di atas, secara meyakinkan dapat dikatakan bahwa diklat singkat modelmodel pembelajaran bagi pengawas PAI telah menunjukkan efektivitasnya yang nyata, dalam arti kata program pembinaan pengawas PAI Kementerian Agama dapat dijadikan salah satu acuan untuk meningkatkan kompetensi pedagogik pengawas PAI Kementerian Agama.

\section{Kesimpulan}

Program pembinaan pengawas PAI Kementerian Agama Provinsi Sumatera Selatan melalui diklat singkat model-model pembelajaran sudah teruji valid, berdasarkan hasil validasi para ahli materi, ahli kurikulum dan ahli bahasa diperoleh rata-rata validasi sebesar 97,47\% (Valid/layak), artinya pengembangan program pengawas PAI Kementerian Agama Provinsi Sumatera Selatan melalui diklat singkat model-model pembelajaran sudah layak untuk digunakan. 
Pengembangan program pembinaan pengawas PAI Kementerian Agama Provinsi Sumatera Selatan melalui diklat singkat model-model pembelajaran yang dikembangkan teruji praktis untuk digunakan, berdasarkan hasil tanggapan dari pengawas PAI Kementerian Agama Sumatera Selatan yang dijadikan subyek dan dimintai tanggapan terhadap program pembinaan dan materi diklat mencapai 98,75\% (praktis/layak). Pengembangan program pembinaan pengawas PAI Kementerian Agama Provinsi Sumatera Selatan melalui diklat singkat model-model pembelajaran dapat dijadikan acuan dalam meningkatkan kompetensi pengawas PAI Kementerian Agama Provinsi Sumatera Selatan sehingga dapat mempengaruhi peningkatan kinerja pengawas PAI itu sendiri.

\section{Daftar Pustaka}

Arikuno, Suharsimi, dan Cepi Safruddin Abdul Jabar. (2010). Evaluasi Program Pendidikan, Pedoman Teoritis, Praktis Bagi Mabasiswa dan Praktisi Pendidikan. Jakarta: Bumi Aksara.

Borg, Walter R and Meredith D Gall, Joyce P. Gall. (2007). Educational Research (Introduction). USA: Pearson Education.

Daryanto, dan Tutik Rachmawati. (2015). Supervisi Pembelajaran, Inspeksi Meliputi Controlling, Correcting, Judging, Directing, Demonstration. Jakarta: Grava Media.

Hamalik, Oemar. (2014). Perencanaan Pengajaaran Berdasarkan Pendekatan Sistem. Jakarta: Bumi Aksara.

Hasbullah. (2010). Otonomi Pendidikan, Kebijakan Otonomi Daerah dan Implikasinya terhadap Penyelenggaraan Pendidikan. Jakarta: Rajawali Pers.

Hendarman. (2015). Revolusi Keinerja Kepala sekolah. Jakarta: Permata Puri Media.

Imron, Ali. (2012). Manajemen Peserta Didik Berbasis Sekolah. Cetakan kedua. Jakarta: Bumi Aksara.

Imron. Ali. (2011). Supervisi Pembelajaran Tingkat Satuan Pendidikan. Jakarta: Bumi Aksara.

Mulyasa, E. (2012). Manajemen dan Kepemimpinan Kepala Sekolah. Jakarta: Bumi Aksara.

Nurbaiti. (2016). Pengelolaan Kelas (Classrooom Management). Surakarta: CV Mitra Banua Kreasindo.

Rifa'i, Ahmad. (2020). Pelaksanaan Manajemen Kurikulum Sistem Blok di Program Studi Agribisnis Fakultas Industri Halal UNU Yogyakarta. An Nur: Jurnal Studi Islam. Vol. 12 No.2. 
Sahertian, Piet. A. (2000). Konsep Dasar dan Teknik Supervisi Pendidikan dalam Rangka Pengembangan Sumber Daya Manusia. Jakarta: Rineka Cipta.

Su'ud, Udin Syaefudin, dan Abu Syamsuddin Makmun. (2007). Perencanaan Pendidikan Suatu Pendekatan Komprehenship. Bandung: Remaja Rosdakarya.

Sudijono, Anas. (2007). Pengantar Evaluasi Pendidikan. Jakarta: PT. Raja Grafindo Persada

Sugiyono. (2012). Metode Penelitian Kuantitatif, Kualitatif, dan Kombinasi (Mixed Method). Bandung: Alfabeta.

Surachim, Acim. (2016). Efektivitas Pembelajaran Pola Pendidikan Sistem Ganda. Bandung: Alfabeta. 